\title{
Update on chronic viral hepatitis
}

\author{
K Walsh, G J M Alexander
}

\begin{abstract}
Many recent and significant advances in the field of chronic viral hepatitis, including therapy, suggest that an update on chronic hepatitis is timely.
\end{abstract}

Chronic hepatitis $B$ virus infection remains a significant worldwide cause of liver cirrhosis and hepatocellular carcinoma, despite the wide availability of a long established and effective vaccine. Transmission occurs via perinatal, sexual, and parenteral routes (particularly intravenous drug abuse and although blood products still carry a risk, this is now extremely low in Western countries). Only a minority of infected adult cases develop chronic hepatitis but in children under 1 year, $90 \%$ develop chronic hepatitis. The clinical spectrum of chronic liver injury ranges from mild inflammation to end stage liver cirrhosis. Interferon alfa has been the mainstay of treatment for patients with active disease but nucleoside analogues (lamivudine and adefovir) are now available with similar efficacy. Patients with end stage liver disease and hepatocellular carcinoma can be offered transplantation but infection in the graft is commonplace. The combination of hepatitis $B$ immunoglobulin and newer antiviral drugs reduce the incidence and severity of graft infection significantly.

The hepatitis $C$ virus epidemic of the latter half of the 20th century now affects more than $1 \%$ of populations worldwide. This RNA virus is spread parenterally and is becoming the leading indication for liver transplantation. The majority of patients develop chronic hepatitis, which may be progressive, evolving to significant liver disease (cirrhosis or hepatocellular carcinoma) in about $20 \%$ cases after decades. Treatment with the combination of interferon alfa and ribavirin is successful in up to $40 \%$ cases. Liver transplantation is a therapeutic option for some but graft infection is universal and often complicated by progressive liver fibrosis. A vaccine remains a remote prospect so that prevention is crucial.

Hepatitis $D$ virus infection occurs on a of Medicine, University of Cambridge School of Clinical Medicine,

Addenbrooke's Hospital, Cambridge CB2 2QQ, UK

K Walsh

G J M Alexander

Correspondence to: Dr Alexander gja1000@cam.ac.uk

Submitted 8 February 2000 Accepted 4 September 2000 A number of viruses are known to cause chronic hepatitis. These include hepatitis B and $\mathrm{D}$ viruses identified in the 1960 s and 1970s respectively and hepatitis $\mathrm{C}$ virus isolated in 1989. More recently, newer "hepatitis" viruses such as hepatitis G and TTV have been described, although their role in chronic hepatitis is in doubt. Hepatitis A virus does not cause chronic infection.

\section{Hepatitis $B$ virus}

EPIDEMIOLOGY

Chronic hepatitis B virus (HBV) infection accounts for $5 \%-10 \%$ of cases of chronic liver disease and cirrhosis in the United States. ${ }^{1}$ It affects 350 million people worldwide. The major modes of transmission of HBV are perinatal, sexual (via semen and vaginal secretions), via blood products, and via contaminated needles in intravenous drug addicts. A recent US study found that the prevalence of HBV infection was $4.9 \%$ in serum tested in the period 1988-94. ${ }^{2}$ This was similar to the prevalence of $5.5 \%$ in serum tested in the period 1976-80, despite the widespread availability of vaccination. The prevalence did not increase until puberty suggesting that sexual transmission is the most important route of transmission in that social setting. Other factors associated with increased HBV infection were black race, lower income group, and foreign birth.

\section{VIROLOGY}

The genome of $\mathrm{HBV}$ is a small circular DNA of $3.2 \mathrm{~kb}$, which is the smallest DNA virus known to be pathogenic for humans. HBV replicates in hepatocytes that then secrete hepatitis B surface antigen ( $\mathrm{HBsAg})$, hepatitis $\mathrm{B}$ e antigen $(\mathrm{HBeAg})$, and release intact virions (containing HBV DNA) into the circulation. ${ }^{3}$ Chronic HBV infection is characterised by the persistence of HBV DNA and usually HBeAg in serum. Remissions are characterised by the disappearance of HBV DNA and HBeAg from serum despite the continued presence of HBsAg at lower titre. The pre-core mutation of $\mathrm{HBV}$ is found in a subgroup of patients who are $\mathrm{HBeAg}$ negative and $\mathrm{HBV}$ DNA positive in serum.

\section{CLINICAL COURSE}

Chronicity is dependent mostly upon age at exposure. Thus, $90 \%$ of children infected before their first birthday ${ }^{4}$ become chronic carriers compared to $5 \%-10 \%$ of adults. The majority of patients infected with HBV in the Western world acquire the disease in adulthood and so do not develop chronic infection ${ }^{5}$ whereas in third world countries exposure occurs in the womb, early infancy, or childhood.

Immune compromise results in a less severe 
Table 1 Features found in the various stages of chronic $H B V$

\begin{tabular}{llllll}
\hline Stage & ALT & HBVDNA & $\begin{array}{l}\text { Interface } \\
\text { hepatitis }\end{array}$ & $\begin{array}{l}\text { Cytoplasmic } \\
\text { HBcAg }\end{array}$ & $\begin{array}{l}\text { Nuclear } \\
\text { HBcAg }\end{array}$ \\
\hline 1 & Normal & High & No & Negative & Positive \\
2 & High & Low & Yes & Positive & Positive \\
3 & Normal/low & Negative & No & Negative & Negative \\
\hline
\end{tabular}

In homosexual men coinfected with HIV, the course of chronic HBV is more severe. A study of 132 homosexual men with chronic HBV infection with no history of intravenous drug abuse (65 with HIV) found that HBV replication and progression to cirrhosis were increased in those with HIV. ${ }^{6}$ This supports a cytopathic mode of liver injury.

Three clinical stages of chronic HBV infection can be distinguished (table 1).

(1) Patients have a normal serum alanine aminotransferase and are asymptomatic. They have high serum levels of HBV DNA and HBsAg. Liver biopsy shows the presence of core antigen in nuclei only. These patients will not respond to interferon alfa therapy.

(2) Patients have lower levels of HBsAg and HBV DNA in serum. Liver biopsy shows the presence of core antigen in nuclei and cytoplasm with marked hepatic inflammation. These patients have a high rate of seroconversion from $\mathrm{HBeAg}$ to anti-HBe, which can be accelerated by interferon alfa.

(3) Patients have low levels of HBsAg and are HBV DNA negative in serum. There is no core antigen detectable on liver biopsy and no hepatic inflammation is seen. They may already have progressed to cirrhosis or may have insignificant fibrosis.

Seroconversion from $\mathrm{HBeAg}$ to anti-HBe, either spontaneously or secondary to antiviral therapy, is associated with an improved outcome with reduced liver injury despite the continued presence of HBV DNA in liver. ${ }^{7}$ The natural rate of clearance of $\mathrm{HBeAg}$ is $8 \%-12 \%$ per year. ${ }^{8}$

HBsAg is lost much less often. In a 19 year follow up of $946 \mathrm{HBsAg}$ carriers, the annual rate of clearance of HBsAg was $0.79 \% .{ }^{9}$ Lower HBsAg levels and older age were associated with increased clearance. However, patients may still develop cirrhosis or hepatocellular carcinoma after HBsAg clearance. ${ }^{10}$ In adults there is a male predominance for development of cirrhosis and hepatocellular carcinoma.

Chronic HBV infection is generally benign in children. In 168 Italian and Spanish HBeAg positive children who were followed up for 20 years, 155 became asymptomatic carriers after $\mathrm{HBe}$ seroconversion and had biochemical remission. ${ }^{11}$ Only $6 \%$ cleared HBsAg in the same period.

Ikeda et al estimated the rate of progression to hepatocellular carcinoma in 645 patients with chronic HBV infection to be $2.1 \%$ at five years, $4.9 \%$ at 10 years, and $18 . \%$ at 15 years. ${ }^{12}$

THERAPY

Interferon alfa

This agent has direct antiviral effects but probably depends on its immunomodulatory effects for full effect. Interferon alfa is recommended
Box 1: Factors indicative of a response to interferon alfa

- High serum transaminases.

- Low serum HBV DNA.

- IgM antibodies to HBcAg.

- Active necroinflammation.

- Short duration of disease.

- Absence of complicating disorder.

\section{Box 2: Side effects of interferon alfa}

- Flu-like illness.

- Bone marrow suppression.

- Irritability.

- Inability to concentrate.

- Myalgia.

- Sleep disturbance.

- Depression.

- Weight loss.

- Alopecia.

- Skin rash.

- Fatigue.

- Headache.

- Arthralgia.

for patients with detectable HBV DNA, raised serum transaminases, significant interface hepatitis on biopsy and compensated liver disease. Therapy is given at 10 million units thrice weekly for four months by subcutaneous injection. Response is defined in terms of clearance of HBV DNA and HBeAg, normalisation of transaminases and improvement in liver histology. After an episode of hepatitis in the six to 10 weeks after induction, a long term response with loss of HBsAg is seen in $25 \%-40 \%$ of patients. ${ }^{13}{ }^{14}$ It may take considerable time for HBsAg to be cleared in responders who may develop anti-HBs after 2-7 years. ${ }^{15}$ A recent study with a follow up period of 11 years has shown that interferon alfa has beneficial long term effects in terms of viral clearance, prevention of hepatocellular carcinoma and prolonged survival. ${ }^{16}$ The features that best predict a response to interferon alfa are shown in box $1 .{ }^{14}{ }^{17}$ Side effects seen with interferon alfa are shown in box 2 . Interferon alfa should be used with caution in those with cirrhosis, because of the risk of hepatic decompensation during seroconversion.

\section{Lamivudine}

Lamivudine is a nucleoside analogue that inhibits viral DNA replication. A daily dose of lamivudine $100 \mathrm{mg}$ daily for one year is associated with suppression of HBV DNA levels and substantial histological improvement in chronic hepatitis $\mathrm{B}^{18}$ The major problem has been the development of drug resistant mutations with prolonged therapy. Long term therapy is associated with a higher response rate. Lamivudine is now licensed. 
Adefovir

Adefovir dipivoxil is the oral prodrug of an acyclic nucleotide monophosphate analogue and inhibits viral polymerases and reverse transcriptases selectively with broad spectrum antiviral activity. Initial trials have shown that it is highly effective in reducing replication in chronic $\mathrm{HBV}$ infection. ${ }^{19}$ It is likely to have a major role in the treatment of lamivudine resistant $\mathrm{HBV}$ mutations, since cross resistance is not reported. It is almost certain that a combination of antiviral agents (for example, lamivudine and adefovir) will become standard practice in due course. Adefovir is not yet licensed.

\section{Liver transplantation}

The ultimate treatment of decompensated HBV related cirrhosis or hepatocellular carcinoma is liver transplantation. However, the major drawback has been that HBV infects the graft frequently resulting in a poor outcome. ${ }^{20}$ Fibrosing cholestatic hepatitis is a histological variant of $\mathrm{HBV}$ infection, which in the liver graft has a particularly poor outcome. ${ }^{21}$ Passive immunisation with HBV surface antibody (anti-HBs) - given intravenously as hepatitis B immunoglobulin (HBIg) — can reduce $\mathrm{HBV}$ recurrence to $33 \%$ in those patients who are HBV DNA negative at the time of transplant ${ }^{22}$ but may drive resistant mutations. Thus, in the past, many centres have refused transplantation to HBV DNA positive patients. However, lamivudine has revolutionised our thinking as it has been shown to render patients HBV DNA negative pre-transplant and reduce HBV recurrence post-transplant. ${ }^{23}$ The major problem has been development of resistance to lamivudine. Promising results have been obtained combining HBIg and lamivudine to reduce resistance, since cross resistance does not occur. ${ }^{24}$ Adefovir may also prove valuable in this context.

\section{VACCINES}

Hepatitis B vaccines were introduced in the early 1980s. The initial vaccines contained heat or chemical inactivated subviral particles derived from plasma collected from chronic HBsAg carriers but newer vaccines, for example, Engerix-B (SmithKline Beecham) contain HBsAg particles expressed from recombinant DNA in the yeast Saccharomyces cerevisiae. The vaccines are usually well tolerated with mild injection site reactions occurring in approximately one fifth of cases but fever and systemic reactions are rare. The only contraindication to vaccine administration is hypersensitivity to yeast or to a component of the vaccine. The vaccine is given in three stages, at 0 , one to two months, and at six months. Booster injections are no longer recommended.

Protective anti-HBs titres of $>10$ IU/1 develop in $95 \%-99 \%$ of children and young adults who receive the series of three intramuscular doses. Factors reducing responses are shown in box $3 .{ }^{25}$ The vaccine has been shown to protect against $\mathrm{HBV}$ in all high risk groups including male homosexuals, intravenous drug
Box 3: Factors reducing the efficacy of HBV vaccination

- Smoking.

- Obesity.

- Older age.

- Other immune compromise.

abusers, infants born to HBsAg positive mothers, and health care personnel. ${ }^{26-28}$ Vaccination of the general population has been shown to be remarkably effective in the example of an Eskimo population who have now been followed up for 10 years with none developing chronic hepatitis or becoming HBsAg positive. $^{29}$

Despite successful vaccination in terms of satisfactory anti-HBs levels, some children have developed HBV infection due to an escape mutation in the "a" determinant of the HBsAg epitope driven by HBIg given concurrently. ${ }^{30}$ This mutant may become more common in the next decade. Of some concern is that testing for the mutated HBsAg using modern monoclonal antibody based ELISA may be falsely negative and one has to resort to testing for HBV DNA or using older polyclonal assays to detect HBsAg.

\section{Hepatitis $\mathbf{C}$ virus}

VIROLOGY

By the early 1970s it was appreciated that most cases of post-transfusion hepatitis (also known as non- $\mathrm{A}$, non-B hepatitis) were seronegative for markers of hepatitis A or B virus infections. ${ }^{31}$ Hepatitis $\mathrm{C}$ virus (HCV) was identified finally as the causative virus through molecular cloning of nucleic acids extracted from chimpanzee plasma containing a high degree of non-A non-B infectivity. ${ }^{32}$

$\mathrm{HCV}$ has a positive strand genome that is bound to the nucleocapsid and enveloped by a glycoprotein. There are 9400 nucleotide bases coding for 3000 amino acids. HCV has no DNA intermediate and hence cannot integrate into the host genome, but it does use a negative strand RNA in its replication cycle within the liver. The structure of the HCV genome is illustrated in fig 1 . The three $\mathrm{N}$-terminal HCV proteins (C, E2, E2/NS1) are structural while the four C-terminal proteins (NS2, NS3, NS4, NS5) are non-structural and critical to viral replication. The nucleocapsid and envelope glycoproteins are encoded at the 5 ' end of the genome while the non-structural elements are located at the 3 ' end. The HCV nucleocapsid is well preserved but the envelope and the NS5 regions are highly variable regarding both nucleotide and amino acid sequences. Thus, a number of genotypes of HCV have been described. $^{33}$ At present, the genotypes described are 1a, 1b, 1c, 2a, 2b, 2c, 3a, 3b, 4a, 5a, and $6 a$. The worldwide distribution of the various genotypes is shown in box 4 .

\section{EPIDEMIOLOGY}

Although there are significant regional and ethnic differences, the worldwide prevalence of 


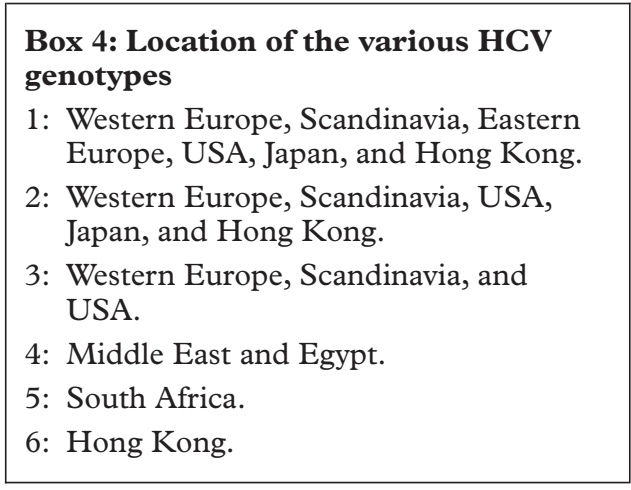

$\mathrm{HCV}$ is thought to be of the order of $1 \%$, with an estimated 300 million carriers. ${ }^{34}{ }^{35}$ In Western Europe, about five million people have chronic HCV infection, which accounts for $40 \%$ of end stage cirrhosis and $30 \%$ of liver transplant candidates. ${ }^{36}$ In the USA, approximately 3.5 million people have chronic $\mathrm{HCV}$ infection, with nearly 150000 new infections annually. ${ }^{34}$ A multicentre study in the UK revealed that $0.61 \%$ of blood donors were antiHCV positive by first generation antibody testing. ${ }^{37} \mathrm{~A}$ study of organ donors in the UK revealed that $0.72 \%$ were anti-HCV positive by recombinant immunoblot assay (RIBA)-2 testing. ${ }^{38}$

Transmission of $\mathrm{HCV}$ is most efficient via the parenteral route with an infection rate greater than $90 \%$ in intravenous drug addicts (box 5). Historical methods of transmission have included transfusion of blood products and transplantation of tissues or organs from infected donors before the introduction of screening for HCV in the early 1990s. Current transmission methods apart from intravenous drug abuse may include tattoos placed with poor hygiene, intranasal cocaine use, and ear piercing. ${ }^{39}$ The risk of $\mathrm{HCV}$ transmission after needlestick injury varies from $0 \%-10 \% \cdot{ }^{40-42} \mathrm{Up}$ to $90 \%$ of haemophiliac patients treated with commercially prepared and unheated clotting factors before 1985 were found to be anti-HCV positive. $^{43}$ As a result of repeated blood transfusion and nosocomial transmission by machines, $10 \%-15 \%$ of haemodialysis patients were found to be infected. ${ }^{44}$

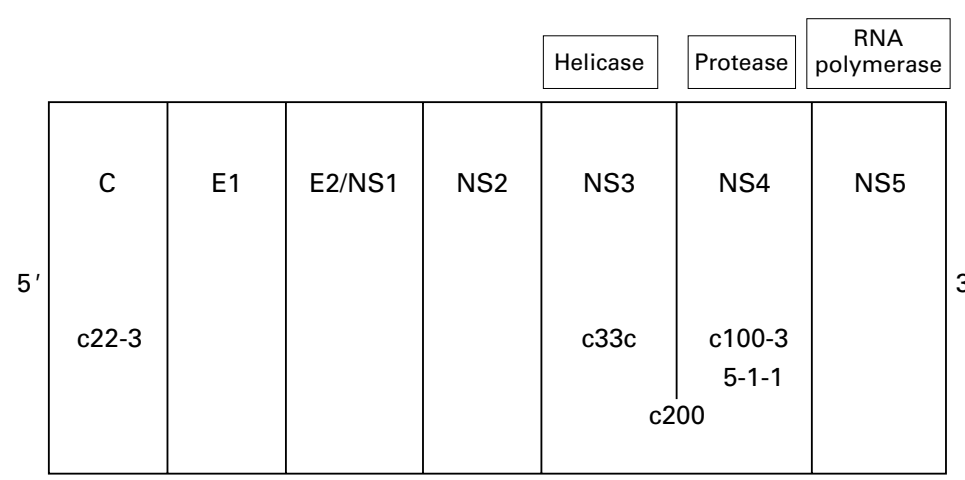

$\begin{array}{ll}\text { Structural Non-structural } & \text { Nom }\end{array}$

Figure 1 HCV genome showing structure of the genome with regions coding for structural (core and envelope) and non-structural proteins.
Box 5: Transmission routes of $\mathrm{HCV}$

- Intravenous drug abuse.

- Blood products.

- Organ transplantation.

- Needlestick injury.

- Tattoos.

- Intranasal cocaine.

- Ear piercing.

- Haemodialysis.

- Perinatal.

- Sexual transmission (possibly).

Vertical transmission can occur and the chance of seroconversion in the infant is related to the maternal viral titre. ${ }^{35}$ Logic suggests that family members should avoid sharing potential sources of infection such as razors and toothbrushes, although no studies have ever been performed to demonstrate protection. Infection of sexual partners in long term relationships occurs very infrequently. ${ }^{45} \mathrm{HCV}$ is not found in semen and patients in a stable sexual relationship are not advised to take extra precautions (EASL and AASLD guidelines).

\section{CLINICOPATHOLOGICAL FEATURES}

Acute $\mathrm{HCV}$ infection is usually subclinical with less than $1 \%$ of patients in the Cambridge series of over 900 patients reporting an acute illness associated with jaundice in relation to $\mathrm{HCV}$ infection. The sinister feature of $\mathrm{HCV}$ infection is the high proportion of patients progressing silently to chronic liver disease with the associated risks of developing cirrhosis and hepatocellular carcinoma. ${ }^{46}$ The histological features seen in chronic HCV are shown in box 6. Various cofactors augment or accelerate HCV mediated liver damage (box 7). Disease progression for chronic $\mathrm{HCV}$ should be measured in years or decades. In one long term follow up study, it took 18.4 years to develop significant chronic hepatitis, 20.6 years to develop cirrhosis, and 28.3 years to develop hepatocellular carcinoma. ${ }^{53}$ Only $20 \%-35 \%$ of infected patients will develop significant liver complications. ${ }^{54}$ It is estimated that $20 \%$ of patients develop cirrhosis after 20 years' duration of infection. Most patients with chronic $\mathrm{HCV}$ have relatively mild symptoms such as fatigue and only develop symptoms or signs with progression to advanced liver disease. Though not evidence based, we, like most liver centres, screen patients with HCV cirrhosis on a six monthly basis for hepatocellular carci3' noma with ultrasound and measurement of $\alpha$-fetoprotein.

While HCV is hepatotropic, it is also found in other tissues including peripheral blood mononuclear cells and lymph nodes and is associated with extrahepatic manifestations (box 8).

\section{DIAGNOSIS}

After exposure, seroconversion to detectable levels of anti-HCV antibodies takes an average 


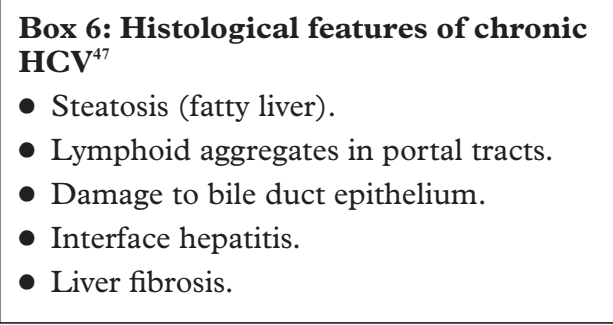

Box 7: Cofactors which may augment
HCV liver injury
- Alcohol. ${ }^{48-50}$
- Hepatitis B. $^{51}$
- HIV.
- Hepatic steatosis.

Box 8: Extrahepatic associations of
HCV
- Type III cryoglobulinaemia..$^{55}$
- Autoimmune hepatitis..$^{57}$
- Membranous glomerulonephritis. ${ }^{58}$
- Porphyria cutanea tarda. ${ }^{59}$
- Diabetes mellitus. ${ }^{60-62}$

of 12 weeks but may take as long as six months. ${ }^{63}$

The original first generation enzyme linked immunosorbent assay (ELISA-1) tested serum for the presence of IgG antibodies to the NS4 region of the HCV genome, the c100-3 antigen. This assay produced too many false positive results. ${ }^{64}$ Soon after, the first generation recombinant immunoblot assay (RIBA-1) was developed. This incorporated the 5-1-1 antigen, another antigen from the NS4 region, in addition to the c100-3 antigen. RIBA-1 had improved specificity compared with ELISA-1. In both assays antibodies were detectable after a mean of 15 weeks (range $0-52$ weeks) after acute infection. Thus, there was a seronegative "window" during which, acutely infected patients may have tested negative.

The second generation ELISA-2 and RIBA-2 assays incorporated additional recombinant antigens from the viral genome. The RIBA-2 test is considered positive when two or more antigens react with the patient serum. Second generation assays have increased specificity and sensitivity and have the advantage that antibodies against c22-3 and c33c appear much earlier (at 30-60 days). ${ }^{65}$ The third generation assays, ELISA-3 and RIBA-3 incorporate additional HCV antigens.

Direct detection of viral RNA using polymerase chain reaction (PCR) is critical in patients infected recently with the virus or in immunosuppressed subjects who may remain antibody negative. In addition, PCR is useful for determining the status of patients with indeterminate antibody profiles. In clinical practice, PCR is useful for detecting viraemia
Box 9: Factors associated with a poor response to interferon alfa

- High viral load.

- Genotype 1.

- Older age.

- Obesity.

- Longer duration of disease.

- Cirrhosis.

- Numerous quasispecies in serum.

in anti-HCV positive patients and in selection for antiviral therapy and monitoring responses. It is important to realise that though patients may be HCV RNA negative in serum, they nearly always are positive for HCV RNA in liver tissue. ${ }^{667}$

THERAPY

The success of antiviral therapy was once defined as normalisation of transaminases but is now based on loss of HCV RNA. Definition of "cure" is remaining serum HCV RNA negative at one year after completion of therapy, ${ }^{68}$ although relapse can still occur; loss of HCV RNA from liver tissue is demonstrated rarely. The ideal measures of response to therapy should be histological remission, prevention of progression to cirrhosis, and reduction in mortality but these long term data are not yet available.

The beneficial effects of interferon alfa alone in non-A, non-B hepatitis were first reported in $1986 .^{69}$ Different regimens exist but the dosage is usually 3-6 million units of interferon alfa thrice weekly for 12-18 months. Higher doses improve responses a little, but lead to intolerable side effects. Response rates in terms of seroconversion to HCV RNA negative were unsatisfactory and varied from $13 \%-20 \%$. Certain factors are associated with a poor response to interferon alfa (box 9). ${ }^{70}$

Most centres now use combination therapy with ribavirin and interferon alfa. Ribavirin is a guanosine analogue with no effect on HCV RNA when given alone. The combination provides a sustained response rate of $38 \%-43 \%$ when given for 12 months. ${ }^{71}{ }^{72}$ Ribavirin has now been licensed for use in combination with interferon alfa for patients who have relapsed after interferon alfa monotherapy as well as for treatment naïve patients with chronic $\mathrm{HCV}$ infection. According to EASL guidelines, combination therapy is recommended for six months in those with genotype 1 and continued for a further six months if patients become HCV RNA negative. In all other genotypes, therapy should be given for six months. The principal side effect of ribavirin is haemolytic anaemia, which usually warrants dose reduction and sometimes withdrawal of the drug. In the UK a decision and guidelines concerning combination therapy are awaited presently from the National Institute for Clinical Excellence (NICE).

Development of new antiviral agents has been hampered by the inability to culture 
HCV. However drugs are being developed that inhibit specific enzyme targets within the $\mathrm{HCV}$ genome, such as the protease and helicase.

All patients with chronic $\mathrm{HCV}$ infection should be vaccinated against HBV (common risk factors) and hepatitis A virus, since the latter is reported to cause fulminant hepatic failure in $\mathrm{HCV}$ carriers. ${ }^{73}$

\section{Liver transplantation}

The only treatment for HCV related end stage liver disease is liver transplantation. Graft infection occurs in almost all cases. At one year after transplant, about $50 \%$ of viraemic patients show evidence of hepatitis on biopsy. ${ }^{74} \mathrm{~A}$ longer term follow up showed that HCV infection is associated with accelerated rates of graft damage in some patients, especially those infected with genotype $1 \mathrm{~b} .^{75} \mathrm{~A}$ recent worrying statistic is that $24 \%$ of patients have become cirrhotic at eight years after transplant. ${ }^{76}$

A recent Italian study has shown a 50\% sustained response rate with combination therapy in transplant patients with $\mathrm{HCV}$ infected grafts, without precipitating rejection. ${ }^{77}$ Others have not achieved such success and combination therapy is considered unproven at present in liver graft recipients. Most centres concentrate on keeping immunosuppression to a minimum with the aim of decreasing HCV replication in the liver graft.

IMMUNOLOGY AND VACCINATION

Development of an effective vaccine is hampered by the extensive genetic and antigenic diversity among different HCV strains. The hypervariable region-1 (HVR-1) undergoes frequent nucleotide substitutions allowing viral persistence. Vaccination with a peptide vaccine of homologous HVR-1 has been effective in the chimpanzee, but high titres need to be maintained to prevent infection. ${ }^{78} \mathrm{HCV}$ infection stimulates the production of neutralising antibodies and cytotoxic lymphocytes but new viral variants that escape these immune responses emerge frequently. ${ }^{79}$ In addition, HCV infection does not confer immunity against reinfection. ${ }^{80}$ Nevertheless, evidence suggests that $\mathrm{CD} 4 \mathrm{~T}$ cell proliferative responses are associated with a more benign course and a better response rate to interferon alfa ${ }^{81}{ }^{82}$ It is of interest that ribavirin enhances this $\mathrm{T}$ cell response. ${ }^{83}$

\section{Hepatitis $D$ virus}

First described in 1977, the hepatitis delta virus (HDV) is a small defective virus that replicates effectively only in the presence of hepatitis B surface antigen (HBsAg). It has been shown in a transplant population that HDV graft infection alone and before HBV graft infection is benign. ${ }^{84}$ Infection is acquired parenterally and probably also via close personal contact in endemic areas. Chronic HDV infection often results in severe liver disease that progresses to cirrhosis in up to $70 \%$ of patients. ${ }^{86}$ Many studies demonstrating the severe course of HDV infection were performed before the identification of $\mathrm{HCV}$; it is possible that in some instances chronic $\mathrm{HCV}$ infection was a cofactor, since HCV and HDV are found in intravenous drug abusers. The prognosis may be worse in those who are coinfected with HBV compared to those where $\mathrm{HDV}$ is a superadded infection in chronic HBV carriers. All patients with HDV have HBsAg in serum but most lack markers of active HBV replication such as HBV DNA and hepatitis B e antigen ( $\mathrm{HBeAg})$. The diagnosis is suspected by finding anti-HDV antibodies in an HBsAg positive patient and confirmed by finding HDV RNA in serum or HDV antigen in liver tissue. ${ }^{86}$

Therapy options are limited. Interferon alfa is effective in only a small proportion and has to be administered at high doses for a prolonged period. ${ }^{87}$ Relapses on cessation of therapy are common unless HBsAg is cleared, which occurs infrequently. ${ }^{88}$ Both ribavirin $^{89}$ and lamivudine ${ }^{90}$ have proved ineffective in chronic delta hepatitis. The best approach is prevention using HBV vaccination.

\section{Hepatitis $G$ virus}

Hepatitis $\mathrm{G}$ virus (HGV) is a recently discovered positive stranded RNA flavivirus, ${ }^{91}$ which was isolated from a surgeon with infective jaundice of unknown cause. Initial enthusiasm for the virus being responsible for non-A, non-B, non- $C$ transfusion related hepatitis has waned. Although found commonly in chronic HCV carriers, it has been shown to have no impact on liver disease severity or response to antiviral therapy. ${ }^{92} 93$ Similarly, it has been shown to have no influence on the course of HBV. ${ }^{94}$ HGV positive blood donors are no more likely to have raised transaminases than HGV negative donors. ${ }^{91}$ HGV RNA could not be detected in the explant livers of 54 patients with cryptogenic cirrhosis. ${ }^{95}$

\section{TT virus}

First described in 1997, TT virus is an unenveloped single stranded DNA virus, which was described in the sera of $3 / 5$ patients with biopsy proved non-A to $G$ post-transfusion hepatitis. ${ }^{96}$ Further Japanese studies have indicated a possible causative role for TT virus in chronic hepatitis. ${ }^{97} 98$ However, studies from the UK and USA suggest that although the virus is detected commonly in blood donors, it is not clear if it has any pathogenic role in hepatitis. ${ }^{99-101}$

1 Alter MJ, Mast EE. The epidemiology of viral hepatitis in the United States. Gastroenterol Clin North Am 1994;23:43755 .

2 Mcuillan GM, Coleman PJ, Kruszon-Moran D, et al. Prevalence of hepatitis B virus infection in the United States: the National Health and Nutrition Examination Surveys, 1976 through 1994. Am F Public Health 1999;89:14-8.

3 Lau JYN, Wright TL. Molecular virology and pathogenesis

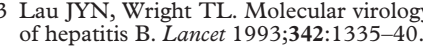

4 Moyer LA, Mast EE. Hepatitis B: virology, epidemiology, disease, and prevention, and an overview of viral hepatitis. Am $\mathcal{F}$ Prev Med 1994;10(suppl): 45-55.

5 McMahon BJ, Alward WL, Hall DB, et al. Acute hepatitis B virus infection: relation of age to the clinical expression of disease and subsequent development of the carrier state. $\mathcal{F}$ Infect Dis 1985;151:599-603.

6 Colin J-F, Cazals-Hatem D, Loriot MA, et al. Influence of human immunodeficiency virus infection on chronic hepatitis B in homosexual men. Hepatology 1999;29:130610 .

7 Ruiz-Moreno M, Otero M, Millan A, et al. Clinical and histological outcome after hepatitis $\mathrm{B}$ e antigen to antibody seroconversion in children with chronic hepatitis B. Hepatology 1999;29:572-5. 
8 Alward WLM, McMahon BJ, Hall DB, et al. The serologic course of hepatitis $\mathrm{B}$ surface antigen and e antigen and the development of primary hepatocellular carcinoma in asymptomatic carriers of hepatitis B virus. F Infect Dis 1985 ; 151:604-9.

9 Fursusyo N, Hayashi J, Sawayama Y, et al. Hepatitis B surface antigen disappearance and hepatitis B surface antigen subtype: a prospective, long-term, follow-up study of Japanese residents of Okinawa, Japan with chronic hepatitis b virus infection. Am F Trop Med Hyg 1999;60:616-22.

10 Huo T, Wu J-C, Lee P-C, et al. Sero-clearance of hepatitis B surface antigen in chronic carriers does not necessarily imply a good prognosis. Hepatology 1998;28:231-6.

11 Bortolotti F, Jara P, Crivellaro C, et al. Outcome of chronic hepatitis B in Caucasian children during a 20 -year observation period. 7 Hepatol 1998;29:184-90.

12 Ikeda K, Saitoh S, Suzuki Y, et al. Disease progression and hepatocellular carcinogenesis in patients with chronic viral hepatitis: a prospective observation of 2215 patients. $\mathcal{F}$ Hepatol 1998;28:930-8.

13 Alexander GJM, Brahm J, Fagan EA, et al. Loss of HBsAg with interferon therapy in chronic hepatitis $\mathrm{B}$ virus infection. Lancet 1987;ii:66-9.

14 Di Bisceglie AM, Fong T-L, Fried MW, et al. A randomized controlled trial of recombinant alpha-interferon therapy for chronic hepatitis B. Am ₹ Gastroenterol 1993;88:1887-92.

15 Korenman J, Baker B, Waggoner J, et al. Long-term remission of chronic hepatitis B after alpha-interferon therapy. Ann Intern Med 1991;114:629-34.

16 Lin S-M, Sheen I-S, Chien R-N, et al. Long-term beneficial effect of interferon therapy in patients with chronic hepatitis B virus infection. Hepatology 1999;29:971-5.

17 Wong DKH, Cheung AM, O'Rourke K, et al. Effect of alpha-interferon treatment in patients with hepatitis B antigen-positive chronic hepatitis B: a meta-analysis. Ann Intern Med 1993;119:312-23.

18 Lai C-L, Chien R-N, Leung NWY, et al. A one-year trial of lamivudine for chronic hepatitis B. N Engl f Med 1998;339: 61-8.

19 Jeffers L, Heathcote E, Wright $\mathrm{T}$, et al. A phase II dose-ranging, placebo-controlled trial of adefovir dipivoxil for the treatment of chronic hepatitis B virus infection (abstract). Antiviral Res 1998;37:A197.

20 O'Grady JG, Smith HM, Davies SE, et al. Hepatitis B virus reinfection after orthotopic liver transplantation. Serological and clinical implications. $\mathcal{F}$ Hepatol 1992;14:104-11.

21 Davies SE, Portmann BC, O'Grady JG, et al. Hepatic histological findings after transplantation for chronic hepatitis B virus infection, including a unique pattern of fibrosing cholestatic hepatitis. Hepatology 1991;13:150-7.

22 Samuel D, Muller R, Alexander G, et al. Liver transplantation in European patients with the hepatitis B surface antition in European patients with the
gen. $N$ Engl f Med 1993;329:1842-7.

23 Grellier L, Mutimer D, Ahmed M, et al. Lamivudine prophylaxis against reinfection in liver transplantation foe prophylaxis against reinfection in liver transp
hepatitis B cirrhosis. Lancet 1996;348:1212-5.

24 Markowitz JS, Martin P, Conrad AJ, et al. Prophylaxis against hepatitis $\mathrm{B}$ recurrence following liver transplantation using combination lamivudine and hepatitis B immune globulin. Hepatology 1998;28:585-9.

25 Wood RC, Macdonald KL, White KE, et al. Risk factors for lack of detectable antibody following hepatitis B vaccinations of Minnesota health care workers. $7 A M A$ 1993;270 2935-9.

26 Szmuness W, Stevens CE, Harley EJ, et al. Hepatitis B vaccine in medical staff of haemodialysis units: efficacy and cine in medical staff of haemodialysis units: efficacy and

27 Francis DP, Hadler SC, Thompson SE, et al. The prevention of hepatitis B with vaccine: report of the Centers
for Disease Control Multi-Center Efficacy trial among homosexual men. Ann Intern Med 1982;97:362-6.

28 Stevens CE, Taylor PE, Tong MJ, et al. Yeast-recombinan hepatitis B vaccine: efficacy with hepatitis B immune globulin in prevention of perinatal hepatitis B virus transmission. fAMA 1987;257:2612-6

29 Wainwright RB, Bulkow LR, Parkinson AJ, et al. Protection provided by hepatitis B vaccine in a Yupik Eskimo population-results of a 10-year study. F Infect Dis 1997;175:674-7.

30 Carman WF, Korula J, Wallace L, et al. Fulminant reactivation of hepatitis B due to envelope protein mutant that escaped detection by monoclonal HBsAg ELISA. Lancet 1995;345:1406-7.

31 Alter HJ, Holland PV, Purcell RH. The emerging pattern of post-transfusion hepatitis. Am F Med Sci 1975;27:29-34.

32 Choo QL, Kuo G, Weiner AJ, et al. Isolation of a cDNA clone derived from a blood-borne non-A non-B viral hepatitis-genome. Science 1989;244:359-62.

33 Simmonds P, Alberti A, Alter HJ, et al. A proposed system for the nomenclature of hepatitis $\mathrm{C}$ viral genotypes [letter] Hepatology 1994;19:1321-4.

34 Esumi M, Shikata T. Hepatitis C virus and liver diseases. Pathol Int 1994;44:85-95.

35 Mansell CJ, Locarnini SA. Epidemiology of hepatitis C in the East. Semin Liver Dis 1995;15:15-32.

36 EASL International Consensus Conference on Hepatitis C. f Hepatol 1999;30:956-61.

37 Garson JA, Clewley JP, Simmonds P, et al. Hepatitis C viraemia in United Kingdom blood donors. A multicentre viraemia in United Kingdom box Sang 1992;62:218-23.

38 Wreghitt TG, Gray JJ, Allain JP, et al. Transmission of hepatitis $C$ virus by organ transplantation in the United Kingdom. F Hepatol 1994;20:768-72.
39 Conry-Cantilena C, VanRaden M, Gibble J, et al. Routes of infection, viremia, and liver disease in blood donors found to have hepat $1691-6$.

40 Mitsui T, Iwano K, Masuko K, et al. Hepatitis C virus infection in medical personnel after needlestick accident. Hepatology 1992;16:1109-14.

41 Lanphear BP, Linnemann CC Jr, Cannon CG, et al. Hepatitis $C$ virus infection in healthcare workers: risk of exposure Arai Y Noda K Enomtrol Hosp Epidemiol 1994;15.745 50. hepatitis C virus infection after needlestick accidents. Liver 1996;16:331-4.

43 Simmonds P, Zhang LQ, Watson HG, et al. Hepatitis C quantification and sequencing in blood products, haemophiliacs, and drug abusers. Lancet 1990;336:1469-72.

44 Galbraith RM, Dienstag JL, Purcell RH, et al. Non-A, non-B hepatitis associated with chronic liver disease in a haemodialysis unit. Lancet 1979;i:951-3.

45 Chayama K, Koboyashi M, Tsubota A, et al. Molecular analysis of intraspousal transmission of hepatitis $\mathrm{C}$ virus. $\mathcal{F}$ Hepatol 1995;22:431

46 Alter MJ, Margolis HS, Krawczynski K, et al. The natural history of community-acquired hepatitis $\mathrm{C}$ in the United States. N Engl f Med 1992;327:1899-905.

47 Goodman ZD, Ishak KG. Histopathology of hepatitis C virus infection. Semin Liver Dis 1995;15:70-81.

48 Frieden TR, Ozick L, McCord C, et al. Chronic liver disease in central Harlem: the role of alcohol and viral hepatitis. Hepatology 1999;29:883-8.

49 Niederau C, Lange S, Heintges T, et al. Prognosis of hepatitis C: results of a large prospective cohort study. Hepatology 1998;28:1710-2.

50 Brunetto MR, Calvo PL, Oliveri F, et al. Hepatitis C virus infection and liver disease: peculiar epidemiological and clinicopathological features. FEMS Microbiol Rev 1994;14: 259-66.

51 Martin P. Hepatitis C infection in patients with chronic hepatitis B: curiosity or co-factor? Am f Gastroenterol 1994; 89:1139-40.

52 Martin P, Di Bisceglie AM, Kassianides C, et al. Rapidly progressive non-A, non-B hepatitis in patients with human immunodeficiency virus infection. Gastroenterology 1989;97: $1559-6$

53 Tong MJ, el-Farra NS, Reikes AR, et al. Clinical outcomes after transfusion-associated hepatitis C. N Engl F Med 1995; 332:1463-6.

54 Di Bisceglie AM, Goodman ZD, Ishak KG, et al. Long-term clinical and histopathological follow-up of chronic posttransfusion hepatitis. Hepatology 1991;14:969-74.

55 Wong YS, Egner W, Elsey T, et al. Incidence, character and clinical relevance of mixed cryoglobulinaemia in patients with chronic hepatitis $\mathrm{C}$ virus infection. Clin Exp Immunol with chronic hepatit

56 Agnello V, Chung RT, Kaplan LM. A role for hepatitis C virus infection in type II cryoglobulinemia. $N$ Engl $f \mathrm{Med}$ 1992;327:1490.

57 Lenzi M. Autoimmune hepatitis and hepatitis $C$ virus infection. FEMS Microbiol Rev 1994;14:247-52.

58 Stehman-Breen C, Alpers CE, Couser WG, et al. Hepatitis $\mathrm{C}$ virus associated membranous glomerulonephritis. Clin Nephrol 1995;44:141-7.

59 Fargion S, Piperno A, Cappellini MD, et al. Hepatitis C virus and porphyria cutanea tarda: evidence of a strong association. Hepatology 1993;17:551.

60 Allison MED, Wreghitt T, Palmer CR, et al. Evidence of a link between hepatitis $\mathrm{C}$ virus infection and diabetes mellitus in a cirrhotic population. F Hepatol 1994;21:1135-9.

61 Ozylkan E, Arsham M. Increased prevalence of diabetes mellitus in patients with chronic hepatitis C infection. Am $\mathcal{F}$ Gastroenterol 1996;91:1480-1.

62 Caronia S, Taylor K, Pagliaro L, et al. Further evidence for an association between non-insulin dependent diabetes mellitus and chronic hepatitis C virus infection. Hepatology 1999;30:1059-63.

63 De Medina M, Schiff ER. Hepatitis C; diagnostic assays. Semin Liv Dis 1995;15:33-40.

64 McFarlane IG, Smith HM, Johnson PJ, et al. Hepatitis C virus antibodies in chronic active hepatitis: pathogenetic factor or false-positive result? Lancet 1990;335:754-57.

65 Alter HJ. New kit on the block: evaluation of secondgeneration assays for detection of antibody to the hepatitis $\mathrm{C}$ generation assays for detection of
virus. Hepatology 1992;15:350-3.

66 Haydon GH, Jarvis LM, Blair CS, et al. Clinical significance of intrahepatic hepatitis C virus levels in patients with chronic HCV infection. Gut 1998;42:570-5.

67 Wong V, Caronia S, Wight D, et al. Importance of age in chronic hepatitis C virus infection. F Viral Hepat 1997;4: 255-64

68 Chemello L, Cavalletto L, Casarin C, et al. Persistent hepatitis $\mathrm{C}$ viremia predicts late relapse after sustained response to alpha-interferon in chronic hepatitis C. Ann Intern Med 1996;124:1058-60

69 Hoofnagle J, Mullen K, Jones D, et al. Treatment of chronic non-A, non-B hepatitis with recombinant human alphainterferon. N Engl F Med 1986;315:1575-8.

70 Chemello L, Cavalletto L, Noventa F, et al. Predictors of sustained response, relapse and no response in patients with chronic hepatitis C with alpha-interferon. F Viral Hepat 1995;2:91-6.

71 Poynard T, Marcellin P, Lee SS, et al. Randomised trial of interferon alfa $2 b$ plus ribavirin versus interferon alfa $2 b$ plus placebo for 48 weeks for treatment of chronic infection with 
hepatitis C virus. International Hepatitis Interventional Therapy Group (IHIT). Lancet 1998;352:1426-31.

2 McHutchinson JG, Gordon SC, Schiff ER, et al. Interferon alfa- $2 \mathrm{~b}$ alone or in combination with ribavirin as initial treatment for chronic hepatitis C. N Engl f Med 1998;339 1485-92.

73 Vento S, Garofano T, Renzini C, et al. Fulminant hepatitis associated with hepatitis A virus superinfection in patients with chronic hepatitis C. N Engl f Med 1998;338:286-90.

74 Wright TL, Combs C, Kim M, et al. Interferon alpha therapy for hepatitis $\mathrm{C}$ virus infection after liver transplantation. Hepatology 1994;20:773.

75 Gane EJ, Portmann BC, Naoumov NV, et al. Long-term outcome of hepatitis $\mathrm{C}$ infection after liver transplantation. N Engl f Med 1996;334:815-20.

76 Feray C, Caccamo L, Alexander GJM, et al. European collaborative study on factors influencing outcome after liver transplantation for hepatitis C. Gastroenterology 1999;117: 619-25.

77 Bellati G, Alberti AB, Bell LS, et al. Therapy of chronic hepatitis C after liver transplantation: multicenter Italian hepatitis C after liver transplantation: m
experience. f Hepatol 1999;30 (suppl 1A).

78 Esumi M, Rikihasa T, Nishimara S, et al. Experimental vaccine activities of recombinant E1 and E2 glycoproteins and hypervariable region 1 peptides of hepatitis $\mathrm{C}$ virus in chimpanzees. Arch Virol 1999;144:973-80.

79 Shimizu YK, Hijikata M, Iwamoto A, et al. Neutralizing antibodies against hepatitis $\mathrm{C}$ virus and the emergence of neutralization escape mutant viruses. F Virol 1994;68:1494500 .

80 Farci P, Alter HJ, Govindarajan S, et al. Lack of protective immunity against reinfection with hepatitis C virus. Science 1992;258:1135-40.

81 Botarelli P, Brunetto MR, Minutello MA, et al. T-Lymphocyte response to hepatitis $\mathrm{C}$ virus in differen clinical courses of infection. Gastroenterology 1993;104:580 7.

82 Hoffman R, Diepolder H, Zachovel R, et al. Mapping of immunodominant CD4+ T lymphocyte epitopes of hepatitis $C$ virus antigens and their relevance during
chronic infection. Hepatology 1995;21:632-8.

83 Tam RC, Rai B, Bard J, et al. Ribavirin polarizes human T Tam RC, Rai B, Bard J, et al. Ribavirin polarizes human $\mathrm{T}$
cell responses towards a type 1 cytokine profile. $\mathcal{F}$ Hepatol 1999:30:376-82.

84 Davies SE, Lau JY, O'Grady JG, et al. Evidence that hepatitis D virus needs hepatitis B virus to cause hepatocellular damage. Am f Clin Pathol 1992;98:554-8.

85 Rizzetto M, Verme G, Recchia S, et al. Chronic hepatitis in carriers of hepatitis B surface antigen, with intrahepatic expression of the delta antigen: an active and progressive disease unresponsive to immunosuppressive treatment. Ann Intern Med 1983;98:437-41.
86 Negro F, Rizzetto M. Diagnosis of hepatitis delta virus infection. F Hepatol 1995;22:136-9.

87 Farci P, Mandas A, Coiana A, et al. Treatment of chronic hepatitis D with interferon alfa-2a. $N$ Engl f Med 1994;330: 88-94.

88 Battegay M, Simpson LH, Hoofnagle JH, et al. Elimination of hepatitis delta virus infection after loss of hepatitis B surface antigen in patients with chronic delta hepatitis. $\mathcal{F} \mathrm{Med}$ Virol 1994;44:389-92.

89 Garripoli A, Di Marco V, Cozzolongo R, et al. Ribavirin for chronic hepatitis D: a pilot study. Liver 1994;14:154-7.

90 Lau DTY, Doo E, Park Y, et al. Lamivudine for chronic delta hepatitis. Hepatology 1999;30:546-9.

91 Linnen J, Wages J Jr, Zhang-Keck ZY, et al. Molecular cloning and disease association of hepatitis $G$ virus: a

92 Tanaka E, Alter HJ, Nakatsuji Y, et al. Effect of hepatitis G virus infection on chronic hepatitis C. Ann Intern Med 1996; 125:740-3.

93 Bralet MP, Roudot-Thoraval F, Pawlotsky JM, et al. Histopathologic impact of GB virus $\mathrm{C}$ infection on chronic hepatitis C. Gastroenterology 1997;112:188-92.

94 Fattovich G, Ribero ML, Favarato S, et al. Influence of GB virus-C/hepatitis $\mathrm{G}$ virus infection on the long-term course of chronic hepatitis B. Liver 1998;18:360-5.

95 Schiano TD, Fiel MI, Abe K, et al. Absence of hepatitis G virus within liver tissue of patients undergoing liver virus within liver tissue of patients undergoing liver transplantation for

96 Nishizawa T, Okamoto H, Konishi K, et al. A novel DNA virus (TTV) associated with elevated transaminase levels in posttransfusion hepatitis of unknown etiology. Biochem Biophys Res Commun 1997;241:92-7.

97 Okamoto H, Nishizawa T, Kato N, et al. Molecular cloning and characterization of a novel DNA virus (TTV) associated with posttransfusion hepatitis of unknown etiology. Hepatol Res 1998;10:1-16.

98 Ikeda $\mathrm{H}$, Takasu $\mathrm{M}$, Inoue $\mathrm{K}$, et al. Infection with an unenveloped DNA virus (TTV) in patients with acute or chronic liver disease of unknown aetiology and in those positive for liver disease of unknown aetiology and in those posit

99 Simmonds P, Davidson F, Lycett C, et al. Detection of novel DNA virus (TTV) in blood donors and blood products. DNA virus (TTV) in
Lancet 1998;352:191-5.

100 Naoumov NV, Petrova EP, Thomas MG, et al. Presence of a newly described human DNA virus (TTV) in patients with liver disease. Lancet 1998;352:195-7.

101 Charlton M, Adjel P, Poterucha J, et al. TT-virus infection in North American blood donors, patients with fulminant hepatic failure, and cryptogenic cirrhosis. Hepatology 1998;28:839-42. 